International Journal of Instruction e-ISSN: 1308-1470 • www.e-iji.net

Article submission code: 20201101113909

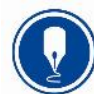

October $2021 \bullet$ Vol.14, No.4

p-ISSN: 1694-609X

pp. 679-694

Received: 01/11/2020

Revision: 15/04/2021
Accepted: 08/05/2021

OnlineFirst: 26/08/2021

\title{
Preservice Teachers Perceptions of Using Case Study as a Teaching Method in Educational Technology Course in Saudi Arabia
}

\section{Taghreed Abdulaziz Almuqayteeb}

Asst. Prof., Imam Abdulrahman Bin Faisal University, College of Science and Humanities Studies, Saudi Arabia, talmuqayteeb@iau.edu.sa

The purpose of this study was to examine preservice teachers' attitudes towards the use of case study method. The study design was action research to investigate the effectiveness of utilizing the case study method. The sample for this study included fourteen master's students enrolled in educational technology in special education course. The results revealed that preservice teachers overall had positive attitudes towards the use of case studies. Also, the case study method was beneficial for improving student's learning, engagement, and critical thinking. This research proves that using the case study method in educational technology course is effective in helping the preservice teachers to both understand appropriate uses of technology and making a meaningful choice of assistive technology corresponding to their student needs. However, there was tendency for some students to believe that the case study method took more time than it was worth, and that they needed more guidance form the instructor about the use of the study. A recommendation resulting from the study was that students needed to understand the teaching approach, its purpose, and its potential for improving student learning for effective implementation of cases in the courses.

Keywords: case study, case-based instruction, educational technology course, critical thinking, educational technology

\section{INTRODUCTION}

There is a growing concern to use new teaching methods in teaching educational technology courses rather than the traditional lecture methods. In recent years, new teaching approaches have been introduced in preservice teacher education. Some of these methods are project-based learning (Hinton, Chicadel, Childress, \& Nix, 2018), problem-based learning (Martin, 2017), or situated learning (Kucuk, 2018). The issues and processes of preparing preservice teachers for their future classroom is vital. Specifically, preparing teachers to effectively integrate technology into the curriculum is crucial. However, teacher educational technology courses usually focus more on basic literacy skills and less on the integration of technologies in their teaching (So \& Kim, 2009; Eom, Shin, \& Han, 2011). Despite various plans to use technology in classrooms,

Citation: Almuqayteeyb, T. A. (2021). Preservice teachers perceptions of using case study as a teaching method in educational technology course in Saudi Arabia. International Journal of Instruction, 14(4), 679-694. https://doi.org/10.29333/iji.2021.14439a 
teachers receive very little training in this area in teacher education programs (Latham \& Carr, 2015; Afshari, Lamm, Telg, Abrams, Myers, \& Raulerson, 2009; Andoh, 2012).

According to Sweeney and Drummond (2013), teacher education programs focus on teaching about technology instead of teaching with technology that support providing the authentic content and pedagogy when technology is introduced or modelled in the courses. Therefore, there is a growing concern about whether preservice teachers are adequately prepared to use technology in a meaningful way in their classes (Ntuli, 2018). Preservice teachers need to envision how they can choose and integrate technology based on their future students' needs. Particularly, special education teachers need to learn how to choose assistive technology for students with disabilities, and those with special needs due to language and other barriers in an authentic way. There are numerous important factors stated in the literature that need to be considered prior to genuine adoption. These factors include teachers' willingness; teacher technology competency (Qahmash, 2018); lack of content-area relevance (Sutton, 2011); perceive usefulness (Wong et al., 2013); and availability and access to technology, ease of use, familiarity with technology, and students' motivation (Kalonde \& Mousa, 2016). Thus, teaching special education teachers on how to integrate technology in their classroom teaching based on their students' needs is vital.

Literature suggests that learning is best when it involves real problems and active thinking and practice (Beckisheva, Gasparyan, \& Kovalenko, 2015; Ray, 2018). The use of case study is an instructional technique that focuses on student-centered learning and engagement in authentic problem solving. Case study method has also been reported as a potential approach for enriching students' experiences by providing opportunities to combine content knowledge and pedagogical knowledge learned in various teacher preparation courses (Baker, 2009; Kim, 2011). Furthermore, case-based learning has proven to be effective in developing students' critical thinking skills because of the realworld experience a case study brings to the learning environment (Akins, Lamm, Telg, Abrams, Meyers, \& Raulerson, 2019). By engaging students in case studies, students had longer-lasting knowledge because it boosted individual reflection as well as group reflection when working together (Forsgren, Christensen, \& Hedemalm, 2014). It also encouraged active learning, and promoted more enthusiasm in the course (Popil, 2011).

Case study has been an effective pedagogical tool in social education such as Business and Law (Strelchonok, 2018; Bayona \& Castaneda, 2017; Shin, Brush, \& Saye, 2014). However, its potential in educational fields such as educational technology, needs to be fully explored. The empirical research on the effectiveness of case studies on student engagement and critical thinking related to choosing the suitable technology based on students' special needs is limited. The researcher is not aware of any study that particularly have discussed the use of cases studies in educational technology courses in special education. Prior studies have focused on various factors that influence preservice teachers' integration of technology (Qahmash, 2018; Sutton, 2011; Kalonde \& Mousa, 2016) and various suggestions to deal with these factors (Andoh, 2012; Sadaf, Newby, \& Ertmer, 2015). However, these studies did not discuss applying new instructional methods that may support preservice teachers' learning in educational technology courses. This study aimed to examine the use of the case study method teaching not only 
to teach the content of technology, but also to develop analytical and decision-making skills in choosing the suitable technology for special students. To address this issue, this paper examines preservice teachers' attitudes towards the use of case study method. Specifically, the research aimed to answer the following research question: What are the attitudes of preservice teachers towards the use of case studies in terms of their learning, engagement, and critical thinking?

\section{Literature Review}

Research suggests that teacher preparation programs do not sufficiently address preservice teachers' needs for technology integration, because educational technology courses do not take into consideration content knowledge in its modules (Sutton, 2011). Having basic computer skills is not enough because preservice teachers need to be prepared for developing e-content in teaching and learning process (Avci et al., 2016). Therefore, technology integration should not be addressed as a distinct construct but should be addressed in an integrative way that cannot be achieved in traditional lectures. Case study is an innovative teaching method that can be used to teach different subjects such as science, technology, or language because it employs a variety of practical reallife situations that can be used to provide context and articulate theoretical concepts (AlMansour \& Hussain, 2014). Using case study as a teaching method will provide dynamic interactions in teaching practices. Also, case studies provide students with opportunities to apply theoretical knowledge to practical situations (Han, Eom, \& Shin, 2013). Applying case study in educational technology courses will support students in having opportunities to practice choosing the suitable solutions, in this case 'computer technologies', based on the cases study scenarios and taking in consideration the content of the lessons and students' needs.

\section{Case Based Instruction}

Case Based Instruction (CBI) is an active teaching method with the possibility to improve the quality and quantity of students' learning practices (Razali \& Zainal, 2013). The use of case studies in teaching introduces complex, real life or scenarios cases into an educational setting to practice making significant decisions (Razali \& Zainal, 2013; Liubchenko, 2016; Yadav \& Barry, 2009). Usually, cases are presented in a story form, and often include problem solving that is related to some course materials or topics, and discussions by students in groups or the whole class (Beckisheva et al., 2015). CBI stimulates students to think more deeply and to introduce their views more freely. Also, it allows students to apply their theoretical knowledge to practical situations in a supportive environment without worrying about the effect of their decisions (Yadav, Shaver, \& Meckl, 2010). Case Based Instruction has been used in various professional fields, such as medicine, business, engineering, law, and others to teach students to work in complex situations and prepare students to apply what they learned in real life (Yadav et al., 2010). Previous research has shown positive impact of case studies on a broad range of professional and educational outcomes. For example, case studies promote academic performance (Schunk et al., 2012), critical thinking (Bowe et al., 2009; Yadav et al., 2010), motivation to participate in class activities (Murray-Nseula, 2011; LusterTeasley, Hargrove-Leak, Gibson, \& Leak, 2017), self-efficacy (Yalcinkaya, Boz, \& Erdur-Baker, 2012), and students' oral and written communication skills (Bonney, 2015). 
Case studies have been found to make the content easier to recall and make the class more enjoyable for students (Simpkins, Yuan, Yu, \& Williams, 2015; Yadav et al., 2010). A study by Yadav et al. (2010) investigated the effect of Case Based Instruction on undergraduate mechanical engineering students' conceptual knowledge and their attitudes towards the use of case studies. Seventy-three students from two sessions of mechanical engineering course were surveyed. They were given pre-tests, post-tests, and a survey questionnaire to assess their conceptual knowledge and engagement in case studies. The two sessions were both taught using traditional lectures and the case study teaching method. The results revealed that most students had positive attitudes toward the use of case studies. Most participants felt that the use of case studies enrich their experiences by engaging them in class work and adding a lot of realism to the class. However, there were no significant differences between traditional lecture and case based instructional methods on students' conceptual understanding.

Case studies have also been effective in making the students active learners. In a study by Ray (2018), the researcher examined the adoption of 'case-studies' teaching technique in two economics courses taught by the same instructor in a small liberal arts college. Using a questionnaire, the researcher assessed students' learning experiences using case studies. The researcher found that learning through 'cases' was effective in enhancing students' academic achievement and in making the students active learners in the course (Ray, 2018). Furthermore, the results revealed that students found that casestudies support their learning in using economics to solve real problems in the course.

Case studies have also been found to increase students' critical thinking. Akins et al. (2019) investigated the impact of case study integration on critical thinking style in communication courses that included content about agriculture and natural resources (ANR) issues for 83 students using pre and post-tests. The researcher assessed if students' critical thinking styles changed because of the case study integration. The researcher found that the integration of case studies significantly encouraged students to seek out information and engage with others more than students who took the same course without case studies. The researchers concluded that case studies should be integrated into the classroom to encourage critical thinking.

\section{Case Experience in teacher education}

Case study is an innovative teaching method that can be used to teach various subjects such as science, technology, or language because it employs a variety of practical reallife situations that can be used to contextualize and articulate theoretical concepts (AlMansour \& Hussain, 2014). In a teacher education context, researchers reported that teacher education programs have struggled with choosing and employing the most effective teaching strategies on how to prepare preservice teachers to integrate technology in their future classrooms (Goktas, Kucuk, Aydemir, Telli, Arpacik, Yildirim, \& Reisoglu, 2012). Many programs emphasized technological training in authentic teaching situation experiences that successfully integrate technology into instructional practice (Latham \& Carr, 2015; Andoh, 2012). In this regard, preservice teacher education programs provide numerous approaches throughout their curriculum like information provision of technology integration matter (e.g., lectures, videos), 
hands-on technology skill activities (e.g., presentations), and technology integration practice in real classrooms (e.g., field experiences) (Ottenbreit-Leftwich et al., 2010; Polly et al., 2010).

While case studies have been employed in different disciplines, very little research has reported their application in educational technology courses. Han et al. (2013) investigated the effects of multimedia case-based learning on 78 preservice teachers' knowledge integration related to teaching with technology. Preservice teachers were provided with discussions that included either video cases or no cases. The results revealed that video cases improved preservice teachers' perceived learning of technological and pedagogical knowledge, and knowledge integration in the specific areas. However, the researchers found that content related to technology integration knowledge was not developed by applying case-based learning (Han et al., 2013; Sutton, 2011).

In a study by Kim and Hannafin (2011), the researchers studied how preservice teachers gain situated knowledge about teaching with technology by engaging them in the experiences of practicing teacher through Web-enhanced, Case-based activities. They also found that case-based activity improved preservice teachers' perceived learning of technological and pedagogical knowledge, and knowledge integration of these knowledge areas. Furthermore, the study found that web-enhanced case-based activity helped preservice teachers to develop meaningful technology integration knowledge, skills, and competences to address a variety of daily classroom teaching and learning issues and practices. These results support the notion that active case-based teaching is an essential component of learning in the twenty-first century (Sharafi, Chamanzari, Rajabpour, Maghsoudi, \& Mazloom, 2016).

For preservice teachers to succeed in the profession, teacher preparation programs are expected to prepare teachers who are capable of effectively integrating new technology into teaching and learning processes (Ntuli, 2018). However, the empirical research on the effectiveness of case studies in teacher education technology courses is limited specifically to special education teachers. The increased interests in adequately preparing teachers to successfully integrate technology into their lessons creates a need to better recognize the best teaching methods that support linking theoretical information to practice, so that preservice teachers can understand the reasons behind using technology in the curriculum (Ntuli, 2018; Jang, 2008a). Previous research on special education teachers' programs have showed that special education teachers still face obstacles to integrate the appropriate assistive technology for students with disabilities such as: lack of content-area relevance and familiarity with assistive technology (Al-Luqmani, 2011; Abdualmajeed \& Alshareef, 2015).

In this study, the researcher investigated the effectiveness of utilizing the case study method in the educational technology course. The research sought to answer the following research question: What are the attitudes of preservice teachers towards the use of case studies in terms of their learning, engagement, and critical thinking? In this matter, cases in teacher education promote preservice teachers' learning by providing them with the opportunities to apply theoretical knowledge in real classroom situations (Kim, 2011). Also, cases have the potential to improve preservice teachers' engagement 
and motivation that increase their perceived value of the content being covered and engage them in the discussions of the best technology which could be used to promote students learning (Han et al., 2013). Furthermore, cases provide preservice teachers with the opportunity to develop analytical and decision-making skills in technology integration process (Kim \& Hannafin, 2011).

\section{METHOD}

This study was guided by answering the research question: What are preservice teachers' attitudes toward the use of case study for learning engagement and critical thinking? In its guidance the researcher employed action research to investigate the effectiveness of utilizing the case study method. The researcher employed a survey followed by interviews to investigate preservice teachers' attitudes towards the use of case studies in the educational technology course. The course "education technology in special education" was a required course that dealt with the use of educational assistive technologies. The students were instructed to choose and integrate assistive technologies according to their students' needs. The present study was implemented during a 15weeks course. Six case studies were introduced to students separately in different weeks. Using the case study method allowed for extensive use of discussions and the views of students were sought and acted upon in relation to the case and the subject of the day. Additionally, the students were encouraged to share their ideas with their peers. All the case studies were acquired from a web-based data for special education. These cases studies describe different situations of students with disabilities in an instructional environment. The students were provided with the case study during class after discussing the objectives of the topic. Students were asked to analyze the problem of the case, describe the appropriate diagnosis of the case, and finally decide which kind of assistive technology could be integrated into their lesson to support student's learning. The goal in the case method teaching was not only to teach the content of technology, but to develop analytical and decision-making skills. In this method, not only is the instructor able to see how participants respond differently to a challenge/problem, but also students are able to see how their points of view differ during selecting the suitable assistive technology with special education students. This helps students increase their learning and have fun too.

\section{Participants}

The setting of this study was an educational technology course for master's special education teachers titled "educational technology in special education" a three-credit semester course for students in their first year of master's degree. The study participants consisted of fifteen students who are enrolled in educational technology in special education course. The course introduces Assistive Technology (AT) which is defined as "any item, piece of equipment, software, or product system, whether acquired commercially off the shelf, modified or customized, that is used to increase, maintain, or improve functional capabilities of individuals with disabilities" (Individual with Disabilities Act, 2004, 602.1A). For this study, students were asked to model using and integrating assistive technology tools in their lessons. All the students were enrolled in the special education master's program in the College of Science and Humanities, Imam Abdulrahman Bin Faisal University and were required to take the course. 
Data were collected by employing a survey and followed by interviews. Students completed a 23 question Likert scale-item survey. The survey consisted of twenty-three items and was adapted from Yadav et al. (2010) which was designed to assess students' attitudes towards the use of cases studies. In Yadav et al, study, the survey was used to assess students' attitudes towards the use of case studies. The survey used a 5-point Likert scale ranging from Strongly disagree (1) to Strongly Agree (5) (Yadav et al., 2010).

The survey in this study was used to assess preservice teachers' attitudes towards the use of case studies in the educational technology course. Students were asked about their perceptions of the impact of case studies on their learning, engagement, and critical thinking (Table 2). Internal reliability of the survey and each subscale was determined by using Cronbach's Alpha: Overall $(\alpha=0.97)$, learning $(\alpha=0.95)$, critical thinking ( $\alpha$ $=0.97)$, and engagement $(\alpha=0.91)$. Subsequently, students were asked to participate in an interview to gain more details about their attitudes towards using the case study method. The interview questions consisted of 4 questions and was adapted from Razail and Zainal (2013) who investigated students' acceptance of the case study method in software engineering education course. Seven students agreed to participate in the interview, and it consisted of four questions reflecting on their experiences using case method in class:

Question 1. Do you prefer this kind of exercise or the traditional way? Why?

Question 2. Was using the case study useful to you? Yes or No? In what aspects is it useful/not?

Question 3. What if this kind of exercise is included in the examination? Do you like it or not? Why?

Question 4. Do you prefer to have this kind of exercise as a take home assignment or as a classroom-based activity? Which one? Why?

\section{Data Analysis}

The data was analyzed quantitatively using descriptive statistical analysis and qualitatively through coding and content analysis. Gay and Airasian (2003) stated that descriptive studies are "useful for investigating a variety of educational problems, and is concerned with assessing attitudes, opinions, preferences, demographics, and procedures" (p. 277). A descriptive statistical analysis using means, percentages, and standard deviations was used to describe the demographic variables and to determine students' attitudes towards the use of case studies in the educational technology course.

\section{FINDINGS AND DISCUSSION}

\section{General information from the respondents}

In this study, a quantitative research design has been used to analyze the results. The study achieved a $93.3 \%$ response rate, 14 out of the total sample of 15 master's students in the College of Science and Humanities at the Imam Abdulrahman Bin Faisal University in Saudi Arabia. The first part of the survey was concerned with the collection of demographic information such as participants' age, major, teaching experience, university, having a special needs family member, and prior experience of 
learning with cases. This information was useful to understand the background of all the respondents that facilitated in testing different variables. Table 1 provides some students

Table 1

Preservice teachers' participants' characteristics

\begin{tabular}{|c|c|c|c|}
\hline Variables & Categories & Frequency & Percentage \\
\hline \multirow[t]{5}{*}{ Age } & $20-25$ & 4 & $28.6 \%$ \\
\hline & $26-30$ & 9 & $64.3 \%$ \\
\hline & $31-35$ & 1 & $7.1 \%$ \\
\hline & More than 35 & 0 & 0 \\
\hline & Total & 14 & $100 \%$ \\
\hline \multirow[t]{3}{*}{ Major } & Special Education & 13 & $92.9 \%$ \\
\hline & Other & 1 & $7.1 \%$ \\
\hline & Total & 14 & $100 \%$ \\
\hline Teaching & No experience & 4 & $28.6 \%$ \\
\hline \multirow[t]{3}{*}{ Experience } & $1-5$ & 10 & $71.4 \%$ \\
\hline & More than 5 years & 0 & 0 \\
\hline & Total & 14 & $100 \%$ \\
\hline \multirow[t]{3}{*}{ University } & Imam bin Abdulrahman university & 12 & $85.7 \%$ \\
\hline & Other & 2 & $14.3 \%$ \\
\hline & Total & 14 & $100 \%$ \\
\hline \multirow{3}{*}{$\begin{array}{l}\text { Special needs } \\
\text { family member }\end{array}$} & Yes & 4 & $28.6 \%$ \\
\hline & No & 10 & $71.4 \%$ \\
\hline & Total & 14 & $100 \%$ \\
\hline \multirow{3}{*}{$\begin{array}{l}\text { Prior experience } \\
\text { of learning with } \\
\text { cases }\end{array}$} & Yes & 6 & $42.9 \%$ \\
\hline & No & 8 & $57.1 \%$ \\
\hline & Total & 100 & $100 \%$ \\
\hline
\end{tabular}

Research question: what are the attitudes of preservice teachers towards the use of case studies for learning, engagement, and critical thinking?

The results of the survey revealed that overall preservice teachers had positive attitudes towards the use of case studies in the educational technology course (Table 2). Most of the students felt that case studies allowed them for a deeper understanding of course concepts $(92.8 \%)$, added a lot of realism to the class $(92.9 \%)$, was thought provoking $(92.8 \%)$, and was related to their field of study $(92.8 \%)$. Most of the students felt that the case-based instruction was useful for their learning. Specifically, students reported that the case study was relevant in learning about the course concepts $(85.7 \%)$, was helpful in synthesizing ideas and information presented in the course $(85.7 \%)$ and helped them to analyze the basic elements of the course concepts (78.6\%). In addition, students also reported that using the case study brought together material they had learned in other special education courses $(85.7 \%)$, they were able to apply the course concepts and theories to new situations because of using the case study $(85.7 \%)$ and it allowed them to view an issue from multiple perspectives $(78.5 \%)$.

In addition, students reported that the cases helped them to cover more content in the class $(78.6 \%)$, to analyze the basic elements of the course concepts $(78.6 \%)$, and to retain more from the class $(71.5 \%)$. Students also felt that the cases made the class more engaging with $(92.8 \%)$ reporting that they felt immersed in the activity when cases were used, $71.4 \%$ were more engaged in class when cases were used, and $71.4 \%$ of the 
students took more active part in their learning when the case study was used in the class. Further, $78.6 \%$ of the students reported that the use of cases was challenging in the class, and $92.9 \%$ disagree that the use of case study in the course was inefficient. Lastly, $64.4 \%$ of the students disagreed with the fact that they felt frustrated by the ambiguity of the case study.

Table 2

Preservice teachers' attitude towards the use of case studies

\begin{tabular}{|c|c|c|c|c|c|c|c|}
\hline & $M$ & $S D$ & $\begin{array}{l}\text { Strongly } \\
\text { Disagree }\end{array}$ & Disagree & Neutral & Agree & $\begin{array}{l}\text { Strongly } \\
\text { Agree }\end{array}$ \\
\hline \multicolumn{8}{|l|}{ Learning } \\
\hline $\begin{array}{l}\text { I felt the use of case study was relevant in learning } \\
\text { about the course concepts. }\end{array}$ & 4.36 & 1.15 & 7.1 & 0 & 7.1 & 21.4 & 64.3 \\
\hline $\begin{array}{l}\text { The case study helped me to analyze the basic } \\
\text { elements of the course concepts. }\end{array}$ & 4.29 & 0.82 & 0 & 0 & 21.4 & 28.6 & 50.0 \\
\hline $\begin{array}{l}\text { I felt what we were learning in the using case study } \\
\text { related to my field of study. }\end{array}$ & 4.43 & 0.85 & & 7.1 & & 35.7 & 57.1 \\
\hline $\begin{array}{l}\text { The case study was helpful in synthesizing ideas and } \\
\text { information presented in the course. }\end{array}$ & 4.21 & 1.05 & & 14.3 & & 35.7 & 50.0 \\
\hline $\begin{array}{l}\text { The case study allowed me to retain more from the } \\
\text { class. }\end{array}$ & 4.00 & 1.10 & & 14.3 & 14.3 & 28.6 & 42.9 \\
\hline $\begin{array}{l}\text { I felt that we covered more content by using the case } \\
\text { study in the class. }\end{array}$ & 4.14 & 1.09 & & 14.3 & 7.1 & 28.6 & 50.0 \\
\hline \multicolumn{8}{|l|}{ Critical Thinking } \\
\hline $\begin{array}{l}\text { I thought the use of the case study in the class was } \\
\text { thought provoking. }\end{array}$ & 4.36 & 1.08 & 7.1 & & & 35.7 & 57.1 \\
\hline $\begin{array}{l}\text { The use of case study allowed me for more discussion } \\
\text { of course ideas in the class. }\end{array}$ & 4.21 & 1.12 & 7.1 & & 7.1 & 35.7 & 50.0 \\
\hline $\begin{array}{l}\text { The case study allowed me to view an issue from } \\
\text { multiple perspectives. }\end{array}$ & 4.21 & 1.18 & 7.1 & & 14.3 & 21.4 & 57.1 \\
\hline $\begin{array}{l}\text { The case study allowed me for deeper understanding } \\
\text { of course concepts. }\end{array}$ & 4.29 & 1.06 & 7.1 & & & 42.9 & 50.0 \\
\hline $\begin{array}{l}\text { The case study brought together material I had learned } \\
\text { in several other special education courses. }\end{array}$ & 4.21 & 1.12 & 7.1 & & 7.1 & 35.7 & 50.0 \\
\hline $\begin{array}{l}\text { I was able to apply the course concepts and theories to } \\
\text { new situations as a result of using the case study. }\end{array}$ & 3.93 & 0.99 & 7.1 & & 7.1 & 64.3 & 21.4 \\
\hline \multicolumn{8}{|l|}{ Engagement } \\
\hline The case study added a lot of realism to the class. & 4.29 & 1.06 & 7.1 & & & 42.9 & 50.0 \\
\hline $\begin{array}{l}\text { I was more engaged in class when using the case } \\
\text { study. }\end{array}$ & 4.14 & 1.02 & & 7.1 & 21.4 & 21.4 & 50.0 \\
\hline $\begin{array}{l}\text { I felt immersed in the activity that involved the use of } \\
\text { case study. }\end{array}$ & 4.36 & 1.08 & 7.1 & & & 35.7 & 57.1 \\
\hline $\begin{array}{l}\text { I took a more active part in the learning process when } \\
\text { we used the case study in the class. }\end{array}$ & 4.14 & 1.02 & & 7.1 & 21.4 & 21.4 & 50.0 \\
\hline $\begin{array}{l}\text { I was frustrated by ambiguity that followed when } \\
\text { using the case study. }\end{array}$ & 3.93 & 1.14 & 42.9 & 21.4 & 21.4 & 14.3 & \\
\hline $\begin{array}{l}\text { I felt that the use of case study in the course was } \\
\text { inefficien.t }\end{array}$ & 4.50 & 0.85 & 64.3 & 28.6 & & 7.1 & \\
\hline $\begin{array}{l}\text { I found the use of case study format challenging in the } \\
\text { class. }\end{array}$ & 4.14 & 0.77 & & & 21.4 & 42.9 & 35.7 \\
\hline Most of the students I know like the case study. & 4.00 & 0.87 & & 7.1 & 14.3 & 50.0 & 28.6 \\
\hline $\begin{array}{l}\text { I needed more guidance from the instructor about the } \\
\text { use of the case study in the class. }\end{array}$ & 3.21 & 1.05 & 7.1 & 35.7 & 35.7 & 14.3 & 7.1 \\
\hline The case study took more time than it was worth. & 3.50 & 1.16 & 21.4 & 35.7 & 14.3 & 28.6 & \\
\hline $\begin{array}{l}\text { The case study was more entertaining than it was } \\
\text { educational. }\end{array}$ & 3.50 & 0.94 & 14.3 & 35.7 & 35.7 & 14.3 & \\
\hline
\end{tabular}


The results also revealed that some students have mixed feeling towards using casebased instruction. For instance, 50\% percent of the students disagree with that the cases were more entertaining than they were educational, $14.3 \%$ agreed, and $35.7 \%$ not decided (neutral). Moreover, $21.4 \%$ of the students reported that they needed more guidance from the instructor about the cases in the class while $35.7 \%$ were neutral. Further, the students did not feel that the case study took more time than it was worth $(57.1 \%)$, and $21.4 \%$ agreeing that it did. Overall, preservice teachers had a positive attitude towards the use of case studies in the educational technology course in which most of the students reported that their classmates liked the case study $(78.6 \%)$.

\section{Interview questions}

The results revealed that all the seven participants were in favor of case study method. The participants preferred the case study method because it improved their understanding of the course concepts, allowed exchange of ideas and opinions among peers, enhanced their critical thinking, and increased their collaboration with peers. Also, students revealed that they preferred this method because it added more realness of the situation presented in the case. Some of the students' answers for question 1 stated that the case study:

Participant 2: "help us to apply what we studied in real life situation that we might face in the classroom".

Participant 3: "Yes. Because it is interesting, and it exposed us to real students' conditions that touch our feelings as teachers and how it is possible to support and help these disabled students by choosing the best assistive technology".

Participant 5: "Yes. Because we discuss and exchange ideas and opinions".

For question 2, all the participants found that case study is useful. They found that it helped them to connect theory with practice and promote their critical thinking analysis of the situation. Some actual quotes are as follows:

Participant 6: "Yes. We worked to classify students with different special needs, and then think how to choose/integrate assistive technology in the class considering what kind of disability exists".

Participant 7: "It emphasize higher-order thinking by discussion in the group to find a solution that support students' learning".

For question 3, all students agreed to include case study in the examination. Mainly they liked that because they do not have to memorize, and it depend on evaluating the case study based on their opinions and experiences. Some of the students' answers are below:

Participant 1: "students are free to think, analyze, and present ideas and opinion".

Participant 3: "Better than traditional questions, it will show the student's way of thinking and express their opinion". 
Participant 6: "I do not have to memorize, and I will apply what I have studied in real situation".

Finally, question four asked whether the students prefer the exercise to be a take home assignment or as a classroom-based activity. The results revealed that 2 students preferred to have it as a classroom activity, one student preferred to take it only as home assignment, and 4 students preferred the exercise to be taken both as a take home assignment in which they can prepare and then discuss it as a classroom-based activity so they can exchange ideas and thoughts in class. Some of the students' answers were as follows:

Participant 3: "both will be fine because I would like to have more time to think and research, and then it is important to share it in the class and listen to different perspectives".

Participant 5: "I prefer to have the activity at class because it allows for group discussion, cooperation and promotion of thinking, and new ideas emerge during the discussion".

Participant 6: "It is good to prepare it at home and then come to discuss it at class and benefit from group discussion and promote our thinking to come up with new ideas during discussion".

Participant 7: "Both will be great. I will have time to analyze it and research for answers that will promote critical thinking, and then we come to class and brainstorm with our classmates and share our thought and make decisions".

Results indicated that overall preservice teachers had positive attitudes towards the use of case studies. For example, students felt that introducing the case study allowed them for a deeper understanding of integrating assistive technology and added a lot of reality to the class as if they were dealing with disabled students and had to decide on the best assistive technology to support students' learning. This method helped students to both understand appropriate uses of technology and meaningful choice of assistive technology corresponding to their student' needs. As with previous research, the findings indicate that using case studies provide preservice teachers with the opportunity to learn how to integrate technology (e.g., Han et al., 2013; Kim \& Hannafing, 2011). Also, students reported that they were more engaged when case studies were used. Similarly, researchers observed that case study teaching provided students with a positive and engaging experience (Yadav et al., 2010; Luster-Teasley et al., 2017).

Findings of this study also indicated that preservice teachers have positive attitudes towards using case study as a teaching method; and they agreed to use it as an assessment method. Preservice teachers reported that including case study in the examination will give them a chance to apply what they have learned in real situations, analyze, and present ideas without depending on memorization. Similarly, researchers concluded that case method is suitable in examination because students do not have to memorize everything but understand and evaluate scenarios based on their knowledge and observation (Razail and Zainal, 2013). 
However, the results from this study also suggest that there is a tendency for some students to believe that the case study method takes more time than it is worth, and they needed more guidance from the instructor about the use of case studies pedagogically. Also, half of the students felt that the case study was more entertaining than it was educational. These results indicate that the case study method may not suit all students or every learning environment. Recall that half of the students reported not having prior experience of learning with cases. This suggested that using new instructional method may cause students' resistance to new methods; and that faculty need to progressively introduce case studies to allow students time to adapt to this new method of instruction as well as help students understand the benefits of this teaching method. Furthermore, students may have viewed the case studies as a change from the usual traditional practices rather than viewing them as authentic problems that provide real-world situation issues that should be examined. Therefore, the kind of case studies instructors introduce and how they implemented it in the class plays an essential role in the success of this instructional method.

\section{CONCLUSION AND SUGGESTION}

Overall, the case study method is beneficial for improving preservice teachers' interest and engagement, which has the potential to improve student learning. Key factors to consider for effective implementation of cases in courses are student buy-in and fit. Preservice teachers need to understand the teaching approach, its purpose, and its potential for improving student learning. The researcher believes that when integrating cases into educational technology courses, faculty should clearly set their goals for casebased learning and encourage student reflection upon their field placement. In this case preservice teachers will link what they have discussed in case-based and real classroom experiences.

This study provides directions for future research. Future research may examine how preservice teachers' perceptions of their learning and engagement correspond with their learning outcomes. Moreover, further research could investigate factors that may influence the success of using the case method. In addition, this study was implemented by the researcher by surveying and interviewing master's students; however future research needs to investigate the implementation of cases by observing classes who use cases for the first time in undergraduate courses. This study only focused on assessing preservice teachers' attitudes towards the use of new instructional method. Future research could use measurement tools to assess student learning outcomes. Yadav and Barry (2009) suggested that measuring student learning to assess the effect of a new method is important because it might influence outcome measures. Finally, research is needed to explore the promise of the case study method to promote meaningful technology integration of knowledge and skills for future teachers.

\section{REFERENCES}

Afshari, M., Abu Bakar, K., \& Luan, W., Abu Samah, B., \& Fooi, S. F. (2009). Factors affecting teachers' use of information and communication technology. International Journal of Instruction, 2(1), 77-104. 
Akins, J. L., Lamm, A. J., Telg, R., Abrams, K. Myers, C., \& Raulerson, B. (2019). Seeking and engaging: Case study integration to enhance critical thinking about agricultural issues. Journal of Agricultural Education, 60(3), 97-108.

Al- Mansour, S. N., \& Hussain, S. S. (2014). Introducing case study in classrooms: A holistic approach to language teaching. Journal of Faculty of Languages \& Translation, 161(7), 160-186.

Andoh Charles, B. (2012). Factors influencing teachers' adoption and integration of information and communication technology into teaching: A review of the literature. International Journal of Education and Development using Information and Communication Technology, 8(1), 136-155.

Abdualmajeed, A. H., \& Alshareef, M. M. (2015). Obstacles to integration of educational technologies that teachers of learning difficulties face at elementary stage in the Kingdom of Saudi Arabia. Journal of Educational Sciences, 22, 64-99.

Al-Luqmani, A. H. H. (2011). The reality of developing the educational supervisor the performance of education teachers in the use of educational technologies (A master thesis, Umm Al Qura University, 2011). Shamaa.

Avci, Y., Eren, E., \& Kapucu, M. S. (2016). Practical tools for content development: Pre-service teachers' experiences and perceptions. International Journal of Instruction, 9(2), 19-34.

Bayona, J. A., \& Castaneda, D. I. (2017). Influence of personality and motivation on case method teaching. The International Journal of Management Education, 15, 409428.

Beckisheva, T. G., Gasparyan, G. A., \& Kovalenko, N. A. (2015). Case study as an active method of teaching Business English. Procedia-Social and Behavioral Sciences, 166, 292-295.

Bonney, K. M. (2015). Case study teaching method improves student performance and perceptions of learning gains. Journal of Microbiology \& Biology Education, 16(1), 2128.

Dori, Y., Tal, T., \& Tsaushu, M. (2003) Teaching Biotechnology through case studies Can we improve higher order thinking skills of nonscience majors? Science Education, 87(6),767-793.

Eom, M., Shin, W. S., \& Han, I. (2011). A survey on the differences of pre-service teachers' perception of the technology, pedagogy, and content knowledge (TPACK). The Journal of Korean Teacher Education, 28(4), 141-165.

Forsgren, S., Christensen, T., \& Hedemalm, A. (2014). Evaluation of the case method in nursing education. Nurse Education in Practice, 14(2), 164-169.

Gay, L. R., \& Airasian, P. (2003). Educational research: Competencies for analysis and applications (7th ed.). Upper Saddle River, NJ: Merrill/Prentice Hall. 
Goktas, Y., Kucuk, S., Aydemir, M., Telli, E., Arpacik, O., Yildirim, G., \& Reisoglu, I. (2012). Educational Technology Research Trends in Turkey: A Content Analysis of the 2000-2009 Decade. Educational Sciences: Theory and Practice, 12(1), 191-199.

Han, I., Eom, M., \& Shin, W. (2013). Multimedia case-based learning to enhance preservice teachers' knowledge integration for teaching with technologies. Teaching and Teacher Education, 34, 122-129.

Hinton, C., Chicadel, S., Childress, K., \& Nix, A. (2018). Extending experiential learning opportunities in teacher education: Connecting preservice teachers and their communities through project-based collaborations. Currents in Teaching \& Learning, 10(2), 78-87.

Individuals with Disabilities Education Improvement Act of 2004, Pub. L. No. 108-446 (2004).

Jang, S. J. (2008a). The effects of integrating technology, observation and writing into a teacher education method course. Computers \& Education, 50, 853-865.

Kalonde, G., \& Mousa, R. (2016). Technology familiarization to preservice teachers: Factors that influence teacher educator's technology decisions. Journal of Educational Technology Systems, 45, 236-255.

Kim, H. (2011). Exploring freshmen preservice teachers' situated knowledge in reflective reports during case-based activities. Internet and Higher Education, 14, 1014.

Kim, M.C. \& Hannafin, M.J. (2011). Scaffolding problem solving in technologyenhanced learning environments (TELEs): Bridging research and theory with practice. Computers \& Education, 56(2), 403-417.

Kucuk, S. (2018). How pre-service teachers learn educational technology with the situated learning approach. Journal of Technology and Teacher Education, 26(2), 249274.

Latham, G., \& Carr, N. (2015). Authentic learning for pre-service teachers in a technology-rich environment. Journal of Learning Design, 5(1), 67-77.

Liubchenko, V. (2016). A review of teaching methods for life-long learning. ICTERI.

Luster-Teasley, S., Hargrove-Leak, S., Gibson, W. \& Leak, R. (2017). Case studies in sustainability used in an introductory laboratory course to enhance laboratory instruction. Journal of STEM Education, 18(2), 30-39.

Martin, D. A. (2017). The impact of problem-based learning on pre-service teachers' development and application of their mathematics pedagogical content knowledge. (Doctoral dissertation, University of Southern Queensland, 2017). USQ eprints, https://eprints.usq.edu.au/32851/.

Murray-Nseula, M. (2011). Incorporating case studies into an undergraduate genetics course. Journal of the Scholarship of Teaching and Learning, 11(3), 75 - 85. 
Ntuli, E. (2018). Instructional technology courses in teacher education: A study of inservice teachers' perceptions and recommendations. TechTrends, 62,647-653.

Ottenbreit-Leftwich, A.T., Glazewski, K. D., Newby, T. J. \& Ertmer, P. A. (2010). Teacher value beliefs associated with using technology: Addressing professional and student needs. Computers \& Education, 55(3), 1321-1335.

Polly, D., Mims, C., Shepherd, C. E., \& Inan, F. (2010). Evidence of impact: transforming teacher education with preparing tomorrow's teachers to teach with technology (PT3) grants. Teaching and Teacher Education, 26, 863-870.

Popil, I. (2011). Promotion of critical thinking by using case studies as teaching method. Nurse Education Today, 31(2), 204 - 207.

Qahmash, A., I. (2018). The potentials of using mobile technology in teaching individuals with learning disabilities: A review of special education technology literature. TechTrends: Linking Research and Practice to Improve Learning, 62(6),647653.

Ray, M. (2018). Teaching economics using 'Cases'-Going beyond the 'Chalk-AndTalk' method. International Review of Economics Education, 27, 1-9.

Razali, R., \& Zainal, D. (2013). Assessing students' acceptance of case method in software engineering education - A Survey. Procedia - Social and Behavioral Sciences, 93, 1562-1568.

Sadaf, A., Newby, T., \& Ertmer, P. (2015). An investigation of the factors that influence preservice teachers' intentions and integration of Web 2.0 tools. Educational Technology Research and Development, 64(1), 37-64.

Schaffer, S. P., \& Richardson, J. C. (2004). Supporting technology integration within a teacher education system. Journal of Educational Computing Research, 31(4), 423-435.

Schunk, D. H., Meece, J. R., \& Pintrich, P. R. (2012), Motivation in education: Theory, research, and applications, Pearson/Merrill Prentice Hall, NJ.

Sharafi, S., Chamanzari, H., Rajabpour, M., Maghsoudi, S., \& Mazloom, S.R. (2016). Comparative study on the effect of 'primary nursing' and 'case method' on patients' quality of physical care. Journal of Health Promotion Management, 4(5), 17-23.

Shin, S., Brush, T., \& Saye, J. (2014). Technology-enhanced cases for teacher preparation: The use of the wise practice case database in social studies teacher education. KAERA Research Forum, 1(2), 9-16.

Shin, Y., \& Han, S. (2011). A Study of the elementary school teachers' perception in STEAM science, technology, engineering, arts, mathematics) education. Elementary Science Education, 30(4), 514-523.

Simpkins, L., Yuan, X., Yu, H., \& Williams, K. (2015). Using a case study to teach students about finding and fixing logic flaws in software. EEE Frontiers in Education Conference (FIE), Camino Real El Paso, El Paso, TX, USA, pp. 1-7. 
So, H., \& Kim, B. (2009). Learning about problem-based learning: Student teachers integrating technology, pedagogy, and content knowledge. Australasian Journal of Educational Technology, 25(1), 101-116.

Sutton, S. R. (2011). The preservice technology training experiences of novice teachers. Journal of Digital Learning in Teacher Education, 28(1), 39-47.

Strelchonok, A. (2018). Assessment of case study method implementation in the Business English Teaching. CBU International Conference Proceedings, ISE Research Institute, 6, 790-797.

Sweeney, T., \& Drummond, A. (2013). How prepared are our pre-service teachers to integrate technology? A pilot studies. Australian Educational Computing, 27, 117-123.

Wong, K., Osman, R., \& Goh, P., \& Rahmat, M. (2012). Understanding student teachers' behavioral intention to use Technology Acceptance Model (TAM) validation and testing. International Journal of Instruction, 6(1),89-104.

Yadav, A., \& Barry, B. E. (2009). Using case-based instruction to increase ethical understanding in engineering: What do we know? What do we need? International Journal of Engineering Education, 25(1), 138-43.

Yadav, A., Shaver, G. M., \& Meckl, P. (2010). Lessons learned: Implementing the case teaching method in a mechanical engineering course. Journal of Engineering Education, 99, 55-69.

Yalcinkaya, E., Boz, Y., \& Erdur-Baker, O. (2012). Is case-based instruction effective in enhancing high school students' motivation toward chemistry? Science Education International, 23, 102-116. 